\title{
PRO-GAMBLING CULTURE
}

\section{Maja Brešan}

School of Advanced Social Studies, Slovenia

E-mail: bresan.maja@gmail.com

\begin{abstract}
This paper analyses gambling within the notion of culture. Examining its origins, we find out that gambling is strongly intertwined with culture. Due to human development and cultural complexity, the perceptions of luck, taking risk and chance change over time, but still have an important impact on gambling activity and detecting its codes. Historical evidence of gambling shows that gambling developed with different intensity, and has been mostly affected by European colonization. Gambling culture can be distinguished depending on the historical backgrounds, institutional structure and religious backgrounds (among other factors). The secondary analysis was prepared by taking raw data from the World Value Survey (2014) and analysing the correlations between gambling components. The selected components prove to be significantly correlated with the Taking Risk factor (secularization factor) and represent a significant contribution to the finalization of our findings. The final results propose four types of gambling culture present today, i.e. Simple Gambling Culture, Denied Gambling Culture, Transitioning Gambling Culture and ProGambling Culture. Simple Gambling culture has the least gambling characteristic, whereas Pro-gambling Culture is a newly introduced term which represents the contemporary gambling cultural orientations.
\end{abstract}

Key words: gambling culture, pro-gambling culture, gambling codes, gambling regulations, gambling components

\section{Introduction}

According to G. Reith, one of the leading researchers of gambling, it is a living part of social life, the roots of which can be traced back to early civilizations. Summarizing Reith (2005), at the beginning, gambling was associated with divine powers and God's will. People made the most important decisions by considering the prophets' advice obtained during divine rituals. Growing civilization brought about a new era of chance and probability, mainly through the secularization of society. Gambling as we know today perceives probability to be synonymous with taking a risk with the intention of gaining profit from the initial input. The modern system of social structure is based 
on "risk" and presents the complex view of interpretation of games of chance (Reith 2005).

Gambling is certainly becoming part of our ordinary lives if we consider lottery, scratch cards, slot machines, table and card games, sports betting, etc. as games of chance. Also, all of them can be accessed via internet and landbased casinos. Considering gambling as a cultural phenomenon represents a challenge for gambling studies, therefore, we are going to examine some facts about gambling, religion, and cultural background which are necessary for us to be able to explain its cultural adaptations. The cultural adaptations could also be seen as specific types of gambling culture, which will be presented in this paper. Gambling culture is constantly evolving, mostly because of the impact of online gambling. Even though it is well described by different authors, such as Jan McMillen (2005) and Gerda Reith (2005), it still remains without proper categorization - that is why this paper presents the following four types of gambling culture: i.e. Simple Gambling Culture, Denied Gambling Culture, Transitioning Gambling Culture and Pro-Gambling Culture. This paper begins with defining gambling to provide a broader understanding of gambling practices and cultural involvement. What follows is an overview of gambling studies regarding ethnographic and historical factors and the role of social complexity. The second part of the paper is focused on the formulation of Gambling Culture. The paper continues with examining gambling-related studies and cultural codes, outlining particular cultural codes typical for a specific region or country. Additional data are analysed and presented in the same chapter (taking-risk factor). After summarizing the main literature, the paper suggests four developing stages of Pro-Gambling culture. The paper proposes an extended answer to the development of a gambling society.

\section{Categorizing Gambling at the Level of Culture}

The most common interpretation of culture, as defined by Hofstede (Hofstede et al. 2010), is that of an onion's layers. The layers represent the manifestation of culture at different levels revealing five important elements of the cultural structure: Symbols, Heroes, Rituals, all under the term of Practice. The core of the "Onion" is formed of Values. Values are maintained by being practiced according to how they are interpreted by the members of different cultures. Considering this, we need to examine what gambling is and how we should understand it within the context of culture. Gambling can be interpreted in different ways. According to Per Binde, "gambling is understood as the established practice of staking money or other valuables on games or events of 
an uncertain outcome" (Binde 2005, 2). On the other hand, Clark (1987) points out the value of the reward. He defines gambling as "pertaining to risking of money or something of value on the outcome of a chance event such as a card or dice game" (quoted in Thompson 2015, 12).

In his paper "Gambling Across Cultures: Mapping Worldwide Occurrence and Learning from Ethnographic Comparison" Binde underlines that gambling is not a universal phenomenon, but a pattern of ethnographic and historical developments of circumstances, where the culture embodies these patterns deeply in the human behaviour. Blinde defines gambling as "a social, cultural and economic phenomenon, a remarkably flexible way of redistribution wealth, which is embedded in the socio-cultural systems of societies,..." (Binde 2003, 22). Still, there are some other definitions which mostly define gambling as staking or wagering something valuable to gain profit. Thompson (2015) argues that Gambling is a taking-risk activity which has been transmitted through practices from generation to generation, first under the impact of the colonial era, and in the last decades under the impact of modernization, economics and globalization. On the other hand, Reith supports the idea "that gambling is a mechanism for entering into and prolonging contact with the world of chance"(Reith 2005, 18). We can conclude that gambling is linked to staking something precious or valuable with the hopes of gaining more than the initial input. The reasons why somebody is willing to take risks and stakes can be seen as an adventure, where you believe that you will be the one who was preselected to win, or as Gerda said, to beat the Gods or destiny.

Binde mentions that some factors like the presence of commercially used money, social inequality, social complexity, and the presence of certain kinds of competitive inter-tribal relations may affect the presence and intensity of gambling in societies. Games of chance are associated with the notions of fate, destiny and "the unknown", and they may exist in concord with religion or can, on the other hand, even be in severe conflict with it. Moreover, the author claims that gambling is in an association with societal complexity (Binde 2003, 22).

Townshend (1980) suggests that the more complex a society is, the more likely it is that games of strategy are present in a culture. Considering that, we differentiate between three types of games of chance that are those based on strategy, physical skill and chance, as presented by John Roberts Malcom Arth, and Robert Bush in Games in Cultures published in 1959 (quoted in Binde $2005,13)$. In physical skill games, chance may be involved or not, whereas, strategy games do not include physical skill, but may or may not involve chance. In games of chance neither strategy nor skill should be present. Games of strategy appear to be the models of social interactive systems. Both 
structure and terminology of such strategy games may offer clues to the nature of the interactive system. Games of chance appear to be associated with religious activities. It is commonly believed by many people that the winners of games of chance had received supernatural or magical aid (Roberts et al. 1959, 597-605). Binde $(2005,14)$ concludes that there exists a positive association between gambling and big settlements. In large settlements, gambling is more common. A plausible explanation of this could be that in complex societies, there are cultural codes that promote gambling.

Considering that gambling culture consists of different cultural layers, as described in the paragraph above, we must understand how Gambling Culture was formulated and how it has continued from its roots in old Egypt and developed into the Gambling we know today. In the next chapter, Gambling will be presented from the perspective of the birth of chance, taking risk, and probability, as well as in terms of cultural codes as described by Rapaille (2006).

\section{Conceptualisation of Gambling Culture}

The birth of chance and probability, together with the evolution of taking-risk behaviour, are important notions when talking about gambling culture. Gambling usually has a negative connotation, since we most often deal with its negative influence on society and the psychological deprivations and social distortions it causes. Understanding gambling in a broader sense brings us to the main roots of the human being and cultural development. Gambling is something that has been popular since the times of Babylonia, old China, and India. From Egyptians playing "atep1", the Chinese playing "wei-ch'I2", to fortune telling "pessomancy3", we can observe how society was strongly affected by the idea of predicting what the future holds. There were different objects used in this regard, like bones, dominoes, and pebbles, to the more well-known dice and playing cards (Arnold 1977).

Nowadays, gambling is spreading extremely fast, mostly via internet distribution, bringing gambling directly to our homes. The games' availability

\footnotetext{
${ }^{1}$ Atep is a game of Ancient Egyptians from which the modern game of spoof arose and which required no equipment other than the normal number of fingers (Arnold 1977, 8).

${ }^{2}$ Wei-ch'I is a traditional Chinese board game of territorial possession and capture (en.oxforddictionaries.com).

${ }^{3}$ Pessomancy means divination by means of pebbles. Eearliest use found in Nathan Bailey (d. 1742), lexicographer and schoolmaster. From ancient Greek $\pi \varepsilon \sigma \sigma o ́ \varsigma$ (Attic $\pi \varepsilon \tau \tau o ́ s)$ oval pebble + -mancy (en.oxforddictionaries.com).
} 
allows visitors to choose among a variety of games of chance. The work of Gerda Reith the Age of Chance: Gambling Western Culture (2005) discusses the idea of "chance" through history. The age of faith became the origin of chance in early civilizations, developing the characteristics of taking risks and challenging gods. Random events were first seen as sacred signs from the gods, which could be interpreted to reveal a deep massage from the transcendent "beyond". The separation of "chance" from broadly religious beliefs began in the seventeenth century, indicating not the favour of the gods, but the absence of knowledge. The transformation was intimately connected with gambling. In ancient societies, divination had a decisive role in defining someone's success or failure when taking a risk. Later in the process of foretelling the future, interested parties could entertain themselves by betting on the outcome of rituals, attempting to pre-empt the will of the gods (Reith 2005).

In order to understand the lack of taking risks, it is important to understand "Chance" and "Probability". Plato stated that an individual would be lucky because of fated circumstances, experiencing the right time (Tyche), luck and timeliness (Kairos). On the other hand, Aristotle saw chance as an instance of coincidence or coincidental cause, which does not meet determinism as in Plato's case. From the Christian perspective, chance is seen as fate, astrology, or the will of God, hence the explanation of divine intervention behind miracles (Reith 2005).

The word "probability" seems to appear in the seventeenth century when the numerical idea of randomness can be found. Denying the efficacy of divination and determinism with the law of large numbers can be evidential in the Book II of "De Divinatione" (Cicero quoted in Reith, 2005). This particular secular understanding of the world gave rise to certain knowledge (mathematics and logic) and probability was now a new outcome of understanding chance from the secular view. "It was the development of probability theory itself which made possible the birth of this age, for during its growth, chance began to emerge as a distinct entity in itself, separate from notions of fate or gods. The emergence of chance became visible for the first time parallel to theory of probability between the mid-seventeenth and nineteenth centuries" (Reith 2005, 24).

Once determinism had been secularized, opportunity arose for chance to appear as a neutral phenomenon in its own right. While chance is neutral in this respect, "risk" represents danger and generally implies the possibility of loss. Risk now deals with the knowledge and expression of the calculation of possible outcomes based on the knowledge of the effect of chance on the world. Risk arose from a "secular risk culture" and appeared with modernity. 
Giddens (1991) describes the risk as a transformed perception of society. The institutions of economic markets, labour power and investments are constituted by risk rather than risk being incidental to them (quoted in Reith 2005,40 ). "The risk society oversees the breakdown of certainty and the erosion of metaphysical meaning, for in the Age of Chance the pursuit of knowledge takes the form of the calculation of risk. With the erosion of certainty in knowledge comes the perennial insecurity of modern life" described by Beck (1992) in Risk Society (quoted in Reith 2005, 40-41). There are many authors who deal with risk society and describe it as a part of the capitalist system of production - production of wealth seems to be an ingredient of the social production of "risks".

On the other hand, Binde argues that integration of gambling culture is linked with the global system of trade and communication. It is a shift typically associated with the decisive step in societal development from precapitalist to capitalist, from traditional to modern, and from local to national and then to global. The authors show that the connection with the West has a significant influence on the formulation of gambling. Ethnographic documentation of gambling is relatively well recorded by Americans, which is, however, not the case for middle Asian, African or Muslim countries. The presence of gambling in Europe and regions that had contact with European cultures is shown right before the colonial era (Binde 2005).

However, gambling culture differs from culture to culture and changes depending on its availability, monetary system (if existent), and social norms and social laws (social structure). The idea of restricting gambling in order to maintain social "health" is more fiction than reality. Prohibition does not necessarily mean that gambling activities will not continue being practiced at homes or other places (Binde 2005). "History shows that gambling under such circumstances usually continues to be practiced illegally and only heavy moral pressure restrict enforcement of anti-gambling laws will eradicate it"(Binde $2005,19)$. We assume that tolerating gambling activity in a certain way is now the best option. What is more, regulating the players' activity seems to be a social comprehension. Cultural norms are there to advocate the problem of gambling, and are themselves a part of gambling culture. Religion is also an important indicator of social norms constraining gambling. For example, the Muslim world has strong rules against gambling activities, which for sure restrains gambling activity in these countries, when Christianity is more likely to give the "green light" for gambling activity (even the Bible includes gambling for Jesus' clothing, etc.) than other religions. In addition, in the East, we can find the Chinese religions, Hinduism and Buddhism (and others), as a major reflection of the East. These religions mostly restrain gambling, 
however, after the strong impact colonization had on them, some of these countries have developed a strong gambling culture (World Casino Directory 2018).

From the institutional perspective, gambling as such has strong historical backgrounds in Great Britain and its colonies dating back to the $16^{\text {th }}$ century - dog and horse racing in the USA was the first major expansion overseas. There are a lot of regulated markets/countries which allow gambling as such, but regulate the market in order to collect taxes, protect their own capital and even regulate gambling activities among their citizens (Thompson 2015).

In the next chapter, keys to understanding gambling culture are presented within compared and analysed factors that were retrieved from the World Value Survey, Wave 6 (Inglehart et al. 2014). The final conclusion will collect the challenges and findings about gambling cultures, defined in a model of four types of gambling cultures.

\section{Keys to Unlock the Cultural Codes}

Cultural beliefs and values are passed on to the members of a culture in a number of ways. Firstly, family members or other respected members from an individual's culture can often pass on values or beliefs regarding gambling to other family members directly through modelling their behaviour (Raylu and Oei 2004). Cultural codes as presented by Rapaille (2006) are therefore values, norms and practices which are accepted and welcomed in specific cultures. Cultural values and beliefs can have an influence on gambling patterns in a number of ways. Kassinove, Tsytsarev \& Davionson (1998) and Walker (1992) pointed out two important factors which affect the culture to develop gambling tendencies, namely positive attitudes towards gambling related with the tendency to take risks, and Cultural acceptance - will gambling activity be punished or reinforced (Walker 1992, Kassinove, Tsytsarev \& Davionson 1998, quoted in Raylu \& Oei, 2004, 1096).

Table 1 combines and summarizes some authors' conclusions, from Cracking the Cultural Code (LaTour et al. 2009) of Gambling study to ethnographical facts together with Cultural zones (Inglehart and Welzel 2018) and types of societies (Inglehart, Welzel, and Inglehart and C. Welzel. 2005). To differentiate countries or regions among each other, we refer to cultural zones as defined by Ronald Inglehart and Christian Welzel. They clustered cultural areas into "zones": English-speaking, Latin America, Catholic Europe, Protestant Europe, African, Islamic, South Asian, Orthodox and Confucian ones (quoted in Westwood, 2014). Our observations are divided into specific zones defined by countries. That, however, does not 
mean that all countries match the same gambling characteristics. Table 1 also provides the information about the Global igaming gross win by region share (IGaming Business 2018).

Table 1: Gambling cultures overview

\begin{tabular}{|l|l|l|l|l|}
\hline $\begin{array}{l}\text { Country or } \\
\text { region }\end{array}$ & Culture Zone & $\begin{array}{l}\text { Type of } \\
\text { society }\end{array}$ & $\begin{array}{l}\text { Global } \\
\text { igaming gross } \\
\text { win by region } \\
\mathbf{( 2 0 1 8 )}^{4}\end{array}$ & $\begin{array}{l}\text { Cultural } \\
\text { overview \& } \\
\text { Codes }\end{array}$ \\
\hline $\begin{array}{l}\text { South } \\
\text { America }\end{array}$ & Latin America & $\begin{array}{l}\text { Traditional, } \\
\text { self- } \\
\text { expression } \\
\text { values }\end{array}$ & $\begin{array}{l}\text { Total for Latin } \\
\text { A. and Oceania } \\
1 \% \text { GGW } \\
\text { Mostly loose } \\
\text { gambling } \\
\text { regulations; } \\
\text { gambling laws } \\
\text { in } \\
\text { transformation }\end{array}$ & $\begin{array}{l}\text { Gambling } \\
\text { culture is } \\
\text { present }\end{array}$ \\
\hline $\begin{array}{l}\text { North } \\
\text { America }\end{array}$ & Speaking & $\begin{array}{l}\text { Secular, } \\
\text { self- } \\
\text { expression } \\
\text { values }\end{array}$ & $\begin{array}{l}\text { Tight gambling } \\
\text { regulations }\end{array}$ & $\begin{array}{l}\text { (US) Winners } \\
\text {-purchasing } \\
\text { the American } \\
\text { dream, } \\
\text { mentality } \\
\text { that all have } \\
\text { the chance to } \\
\text { win }\end{array}$ \\
\hline $\begin{array}{l}\text { English } \\
\text { Muslim } \\
\text { World }\end{array}$ & African-Islamic & $\begin{array}{l}\text { Traditional } \\
- \text { Survival }\end{array}$ & $\begin{array}{l}\text { 1\% GGW (value } \\
\text { is significant } \\
\text { just for Africa) }\end{array}$ & $\begin{array}{l}\text { Forbidden by } \\
\text { religion in the } \\
\text { Muslim } \\
\text { world. In } \\
\text { West Africa, }\end{array}$ \\
\hline
\end{tabular}

${ }^{4}$ IGaming Business 2018.

${ }^{5}$ Countries of South America: Argentina, Ecuador, Suriname, Bolivia, Brazil, Guyana, Uruguay, Chile, Colombia, Paraguay, Peru, Venezuela, mostly express as Latin America.

${ }^{6}$ Countries of North America: Antigua and Barbuda, Bahamas, Barbados, Belize, Canada, Costa Rica, Cuba, Dominican Republic, Guatemala, Haiti, Honduras, Jamaica, Mexico, Panama, Saint Vincent and the Grenadines, Trinidad and Tobago, United States of America (USA).

7 World Casino Directory 2018. 


\begin{tabular}{|c|c|c|c|c|}
\hline & & & $\begin{array}{l}\text { Tight gambling } \\
\text { regulations, the } \\
\text { presence of } \\
\text { religious } \\
\text { prohibitions }^{7}\end{array}$ & $\begin{array}{l}\text { gambling is } \\
\text { common. }\end{array}$ \\
\hline Europe & $\begin{array}{l}\text { Catholic } \\
\text { Europe, } \\
\text { Protestant } \\
\text { Europe }\end{array}$ & $\begin{array}{l}\text { Secular- } \\
\text { rational } \\
\text { values, self- } \\
\text { expression } \\
\text { values }\end{array}$ & $\begin{array}{l}\text { 53\% GGW } \\
\text { Tight gambling } \\
\text { regulations }\end{array}$ & $\begin{array}{l}\text { (France) } \\
\text { Mystery - } \\
\text { associated } \\
\text { with money } \\
\text { in a negative } \\
\text { way }\end{array}$ \\
\hline Asia & $\begin{array}{l}\text { Confucian, } \\
\text { South Asia }\end{array}$ & $\begin{array}{l}\text { Secular- } \\
\text { rational } \\
\text { values, } \\
\text { Survival }\end{array}$ & $\begin{array}{l}27 \% \text { GGW } \\
\text { (value includes } \\
\text { Asia and Middle } \\
\text { East) } \\
\text { Combines loose } \\
\text { and tight } \\
\text { gambling } \\
\text { regulations, } \\
\text { depends on the } \\
\text { area }^{7}\end{array}$ & $\begin{array}{l}\text { (China) } \\
\text { Distinctions - } \\
\text { Conflict } \\
\text { between } \\
\text { emerging } \\
\text { capitalism } \\
\text { and } \\
\text { Confucianism, } \\
\text { pressure to } \\
\text { win is high. }\end{array}$ \\
\hline Oceania $^{8}$ & $\begin{array}{l}\text { English } \\
\text { Speaking }\end{array}$ & $\begin{array}{l}\text { Secular, } \\
\text { self- } \\
\text { expression } \\
\text { values } \\
\text { (depends } \\
\text { on a } \\
\text { specific } \\
\text { country) }\end{array}$ & $\begin{array}{l}\text { Total for Latin } \\
\text { A. and Oceania } \\
1 \% \text { GGW } \\
\text { Well regulated } \\
\text { gambling } \\
\text { activites }^{7}\end{array}$ & $\begin{array}{l}\text { Firstly, there } \\
\text { was no } \\
\text { gambling at } \\
\text { all, later it } \\
\text { was } \\
\text { implemented } \\
\text { by Asian } \\
\text { trading and } \\
\text { European } \\
\text { colonization. }\end{array}$ \\
\hline
\end{tabular}

Sources: Own adaptation; World Casino Directory; Ronald Inglehart and Christian Welzel (2018); Inglehart et al. (2014); iGaming Business (2018); LaTour et al. (2009).

As mentioned above, culture can consciously accept gambling activity as something good and pleasant. It can be introduced during primary socialization at home by families when spending time together playing cards, different games of chance, without making any stakes or stakes that do not

${ }^{8}$ Countries of Oceania: Australia, Papua New Guinea, New Zealand, Fiji, Solomon Islands, etc. 
have any value. On the other hand, culture can determine which activities will be "punished". The output of the "childhood memory elicitation" method is a "code" for each culture that, in this instance, represents how that culture's people approach their gambling experience. The code is formed by the cultural environment and remains relatively stable throughout adulthood (Rapaille 2006).

Cracking the Cultural Code of Gambling is a cross-cultural study making a cultural comparison between China, France and the US in order to crack the culture's gambling myth. Using the childhood memory elicitation method, the study indicates that each culture has its own code for gambling. It was conducted in a Las Vegas resort casino with twenty-one gamblers from China, the U.S. and France. They conducted interviews and administered questionnaires in the native language of respondents. After reading and gearing the participants' memory stories, they discussed and developed a series of cultural codes (LaTour et al. 2009).

Based on other authors' findings, Whittington (2001) learnt that gambling in South America was not so common as gambling activity was reported just in Peru, Ecuador, and the Araucanian region (the present Chile). Cooper (1949) mentioned that gambling was present also among the Otomac (in Venezuela) and the Chincha (in Columbia), concluding that most of them took their gambling games very lightly. In Central America, there was no or little gambling, however, everywhere else, betting on rubber-ball games was common practice. In the Post-Classic Period (1000-1530 AD), betting was heavy, involving nobility and common people (Stevenson Day 2001). Culin (1899) stated that North America was a continent of gamblers as gambling was more frequent there. They often used to play with high stakes (quoted in Binde, 2005). Meanwhile in Africa, little or no gambling was present in the south and the southeast of Africa, while it was common in West Africa the area of Congo, River). Gambling in Europe was spread practically among all people, with the exception of some minor areas of the Balkans. The Tibetans, influenced by the Chinese, were a gambling people and also Mongolians were said to have been heavy gamblers (Price 1972). The countries of Oceania had reported no gambling before Asian trading made them play cards. In Malesia, Australia and New Zealand, there was virtually no gambling (Cooper 1941; Kroeber 1948). In Micronesia and Polynesia, only a few peoples could be assumed to have gambled. The ancient Hawaiians were certainly heavy gamblers (Culin 1899). The Muslim ban on gambling was of greater importance in the regions where Islam had been established for centuries 
with the status of the tribal or state religion ${ }^{9}$ (Culin 1899; Cooper 1941, Kroeber 1948, Cooper 1949; Price 1972; Whittington 2001; Stevenson Day 2001; quoted in Binde 2005, 4-6).

Checking the final results from the study Cracking the Cultural Code of Gambling by LaTour et al. (2009), we can recognize that there exists a different mental setting for each country. In the United States, gambling is associated with the nation's western expansion. The Puritan-based culture attempted to control or ban gambling based on moral grounds, but could not withstand the attractiveness of easy money for both, individuals and the government. The authors labelled Americans as Winners. The reason for this is the notion of American dream where everyone has the chance to win and make it big. Even though gamblers understood that the odds were against them, they rationalized their decision to gamble by "Someone here is going to win, why not me?" The second reason hides behind beating the adults - a journey from childhood to adulthood. The third code is on the Catholic Church which supported and embraced gambling (church bingo and casino nights). The last code is Boredom - since people lacked change in their daily lives, winning in the casino gave them a feeling of control over their own destiny (LaTour et al. 2009).

From the author's perspective, the French are viewed as thinkers who see Americans as childish and naïve, but at the same time extremely powerful. The Cultural Code observed in France is Mystery. Gambling is automatically associated with money in a negative way, contrary to the US. Children are told to get a job and not that all is possible as in the US. The French respondent recalled gambling with marbles with siblings or classmates and referred to it as a "wise game". The focus is on not losing and using one's superior mind to crack the system. Mystery is a way of convincing themselves that they are doing nothing wrong. A good gambler is someone who can control the way he or she plays (LaTour et al. 2009).

China's Macau is the only region in the country where gambling is legal. Gambling activity is linked with violence and organized crime. The Chinese are riskier gamblers and show grater illusion of control when compared to the US gamblers (Lau and Ranyard 2005, quoted in Reptille 2006, 478). The Cultural code for China is Distinctions. Emerging capitalism is in conflict with Confucianism, which states "if one's action is guided by profit, one will incur much ill will". The Chinese take gambling seriously and the pressure to win is high. When they are losing, they will bet more because they believe that their luck will return. Money is not the goal of working. They are more focused on

\footnotetext{
${ }^{9}$ North Africa, the Middle East, Persia, all the way to western India.
} 
results than the process. Although gambling has a very negative connotation in Chinese society, many families gambled at home by playing cards and even in casinos - mostly in private spaces. Gambling with small amounts is considered acceptable and part of entertainment, whereas betting big amounts can lead to lack of control. The Chinese claimed no religious views they believe in a type of providence, usually ghosts, spirits or luck. They prefer table games (social games) - social recognition where they can show off their gambling prowess (LaTour et al. 2009).

Pre-colonial time has impacted gambling culture differently around the world as seen in Whittington's study (2001, quoted in Binde 2005). The historical overview shows the macro-level of gambling development and recognizes different mentalities about gambling as such. Looking at Table 1 , we can find the keys which lead us to the next step of our paper. Comparing the information, we can set up four leading gambling culture keys.

1. Key 1: Conceptualization of contemporary gambling culture. Secularrational values are linked to a higher percentage of GGW which shows the aspects of emerging gambling culture in modern societies.

2. Key 2: Impact of religious/cultural restrictions (the Muslim world is a strong representative) - rejecting gambling activities within a culture.

3. Key 3: Transitioning (Oceania, Latin America) - after Asian trading and European colonization, transitioning culture from non-gambling to gambling culture.

4. Key 4: Transitioning values in collision with modernization (Asia) Conflict between capitalism and religious norms, the strong presence of believing in luck.

In the next chapter, we are going to present the Gambling Key Factors which explain the presence of certain gambling behaviour among cultures, mostly the presence of taking-risk behaviour, the meaning of "having fun", and the importance of being rich. The Keys can distinguish gambling cultures among each other, depending on the extent to which something is present or not (e.g. the inclination to taking risks, having fun, etc.).

\section{Gambling Key Factors}

Analysing gambling, per se, means understanding a player's mindset and the importance of certain behaviours marked as impulsive, risky and fun. At a higher level, gambling can be seen as something fun, entertaining and thrilling to people, but also as something forbidden and bad. What is more, gambling stands for taking risks, believing in a possible win, and much more. It is about making choices based on an individual's perception of the game. This 
perception differs at the collective/individual levels, and can be perceived as believing in luck or believing in one's own skills. In this chapter, we are going to start with the selected components of gambling culture (took from World Values Survey data or WVS Wave Six), which are Taking risks, having fun and, the Importance of being rich (Inglehart et al. 2014).

The secondary analysis was made by taking raw data from WVS Wave Six and analysing the correlations between gambling factors. The WVS Wave Six data have been collected between the 2010 and 2014 waves from 60 countries and societies around the world and more than 85,000 respondents (Inglehart et al. 2014). The analized variables are Taking risks, Having a good time, Belonging, and Democracy \& Religious values (see Table 2). The selected data are analyzed by using Regression and Correlations qualitative technique.

Table 2: Gambling factors

\begin{tabular}{|l|l|}
\hline $\begin{array}{l}\text { Gambling factors } \\
\text { (variable) }\end{array}$ & Question \\
\hline Taking risks & $\begin{array}{l}\text { Adventure and taking risks are important to this person; } \\
\text { having an exciting life. }\end{array}$ \\
\hline Having a good time & $\begin{array}{l}\text { Important in life: Leisure time. } \\
\text { It is important to this person to have a good time; to "spoil" } \\
\text { oneself. } \\
\text { It is important to this person to be rich; to have a lot of } \\
\text { money and expensive things. }\end{array}$ \\
\hline Belonging & $\begin{array}{l}\text { This person sees himself as a world citizen. } \\
\text { This person sees himself as an autonomous individual. }\end{array}$ \\
\hline $\begin{array}{l}\text { Democracy \& } \\
\text { Religious }\end{array}$ & $\begin{array}{l}\text { Democracy: Religious authorities interpret the laws } \\
\text { (negative correlation) }\end{array}$ \\
\hline
\end{tabular}

Source: Own study

The Correlation shows that Taking risks \& Adventure, the Importance of being rich, and Having fun are positively proportionally correlated to each other (Pearson Correlation is 0.28; 0.32; and $\mathbf{0 . 3 0}$ - See Table 3). This explains that the more an individual has the need for adventure, wants to have fun and values money, the higher the prospect of taking risks. 
Table 3: Correlation between gambling factors

\begin{tabular}{|c|c|c|c|c|c|}
\hline \multicolumn{6}{|c|}{ Correlations } \\
\hline & & & $\begin{array}{l}\text { Schwartz: } \\
\text { Adventure } \\
\text { and taking } \\
\text { risks are } \\
\text { important } \\
\text { to this } \\
\text { person; to } \\
\text { have an } \\
\text { exciting } \\
\text { life }\end{array}$ & $\begin{array}{l}\text { Schwartz: } \\
\text { It is } \\
\text { important } \\
\text { to this } \\
\text { person to } \\
\text { have a } \\
\text { good } \\
\text { time; to } \\
\text { "spoil" } \\
\text { oneself }\end{array}$ & $\begin{array}{l}\text { Schwartz: } \\
\text { It is } \\
\text { important } \\
\text { to this } \\
\text { person to } \\
\text { be rich; to } \\
\text { have a lot } \\
\text { of money } \\
\text { and } \\
\text { expensive } \\
\text { things }\end{array}$ \\
\hline \multirow[t]{9}{*}{$\begin{array}{l}\text { Spearman's } \\
\text { rho }\end{array}$} & \multirow{3}{*}{$\begin{array}{l}\text { Schwartz: } \\
\text { Adventure } \\
\text { and taking } \\
\text { risks are } \\
\text { important to } \\
\text { this person; } \\
\text { to have an } \\
\text { exciting life }\end{array}$} & $\begin{array}{l}\text { Correlation } \\
\text { Coefficient }\end{array}$ & 1,000 & $285^{* *}$ &, $323^{* *}$ \\
\hline & & $\begin{array}{l}\text { Sig. (2- } \\
\text { tailed) }\end{array}$ & . & ,000 & 000 \\
\hline & & $\mathrm{N}$ & 87312 & 86715 & 86674 \\
\hline & \multirow{3}{*}{$\begin{array}{l}\text { Schwartz: It } \\
\text { is important } \\
\text { to this } \\
\text { person to } \\
\text { have a good } \\
\text { time; to } \\
\text { "spoil" } \\
\text { oneself }\end{array}$} & $\begin{array}{l}\text { Correlation } \\
\text { Coefficient } \\
\end{array}$ & ,285** & 1,000 & ,300** \\
\hline & & $\begin{array}{l}\text { Sig. (2- } \\
\text { tailed) }\end{array}$ & ,000 & . & ,000 \\
\hline & & $\mathrm{N}$ & 86715 & 87965 & 87192 \\
\hline & \multirow{3}{*}{$\begin{array}{l}\text { Schwartz: It } \\
\text { is important } \\
\text { to this } \\
\text { person to be } \\
\text { rich; to have } \\
\text { a lot of } \\
\text { money and } \\
\text { expensive } \\
\text { things }\end{array}$} & $\begin{array}{l}\text { Correlation } \\
\text { Coefficient }\end{array}$ & ,323** & ,300** & 1,000 \\
\hline & & $\begin{array}{l}\text { Sig. (2- } \\
\text { tailed) }\end{array}$ & ,000 & ,000 & \\
\hline & & $\mathrm{N}$ & 86674 & 87192 & 87863 \\
\hline
\end{tabular}

Table 4: Regression of Dependent value - Adventure and taking risks are important to this person; to have an exciting life

\begin{tabular}{|c|c|c|c|c|c|}
\hline \multicolumn{5}{|c|}{ Coefficients $^{\text {a }}$} \\
\hline Model & $\begin{array}{c}\text { Unstandardiz } \\
\text { ed } \\
\text { Coefficients }\end{array}$ & $\begin{array}{c}\text { Standardiz } \\
\text { ed } \\
\text { Coefficient } \\
\text { s }\end{array}$ & $t$ & Sig. & $\begin{array}{c}95,0 \% \\
\text { Confidence } \\
\text { Interval for B }\end{array}$ \\
\hline
\end{tabular}




\begin{tabular}{|c|c|c|c|c|c|c|c|c|}
\hline & & B & $\begin{array}{c}\text { Std. } \\
\text { Erro } \\
\text { r }\end{array}$ & Beta & & & $\begin{array}{c}\text { Lowe } \\
\mathrm{r} \\
\text { Boun } \\
\mathrm{d}\end{array}$ & $\begin{array}{c}\text { Uppe } \\
\text { r } \\
\text { Boun } \\
\text { d }\end{array}$ \\
\hline 1 & $\begin{array}{l}\text { (Constan } \\
\text { t) }\end{array}$ & $\begin{array}{r}1,88 \\
1\end{array}$ & 019, & & $\begin{array}{r}101,26 \\
6\end{array}$ & $\begin{array}{r}, 00 \\
0\end{array}$ & 1,845 & 1,918 \\
\hline & $\begin{array}{l}\text { Importa } \\
\text { nt in life: } \\
\text { Leisure } \\
\text { time }\end{array}$ & ,075, & ,006 & ,039 & 12,168 & $\begin{array}{r}00 \\
0\end{array}$ & ,063 & 087, \\
\hline & $\begin{array}{l}\text { Schwartz } \\
\text { : It is } \\
\text { importa } \\
\text { nt to this } \\
\text { person } \\
\text { to have a } \\
\text { good } \\
\text { time; to } \\
\text { "spoil" } \\
\text { oneself }\end{array}$ & 210 & ,004 & 201 & 59,917 & $\begin{array}{r}00 \\
0\end{array}$ & ,203 & ,217 \\
\hline & $\begin{array}{l}\text { Schwartz } \\
\text { : It is } \\
\text { importa } \\
\text { nt to this } \\
\text { person } \\
\text { to be } \\
\text { rich; to } \\
\text { have a } \\
\text { lot of } \\
\text { money } \\
\text { and } \\
\text { expensiv } \\
\text { e things }\end{array}$ & ,269 & ,003 & ,260 & 77,877 & $\begin{array}{r}00 \\
0\end{array}$ & ,262 & ,276 \\
\hline
\end{tabular}

Taking risks can be explained by seeking adventure, fun and money, as well as how an individual sees himself in the world. We found out that those individuals who view themselves as autonomous individuals are more likely to engage in risk-taking and adventure activities (see Table 3). This can be linked to individualistic point of view where the individual is not as strongly pressured by social norms regarding what is acceptable and what is not. The individual expresses his own will in order to please himself. 
The second finding suggests that individuals who see themselves as world citizens are more likely to engage in adventure and risk-taking. This can be explained in the way that a person with higher income can travel more and have a higher standard or living than others. The usage of the internet is also a good that should not be taken for granted. Feeling as a world citizen has a strong impact on diffusing the feeling of belonging.

Last but not least, individuals who see that in Democracy religious authorities interpret the laws live their lives with more perseverance and are not likely to engage in adventurous and risky situations. Therefore, we may conclude that people who perceive democracy as a secularized process are more engaged in adventures and taking risks than those individuals who see religion as a part of governance.

Table 5: Regression of Dependent value - Adventure and taking risks are important to this person; to have an exciting life

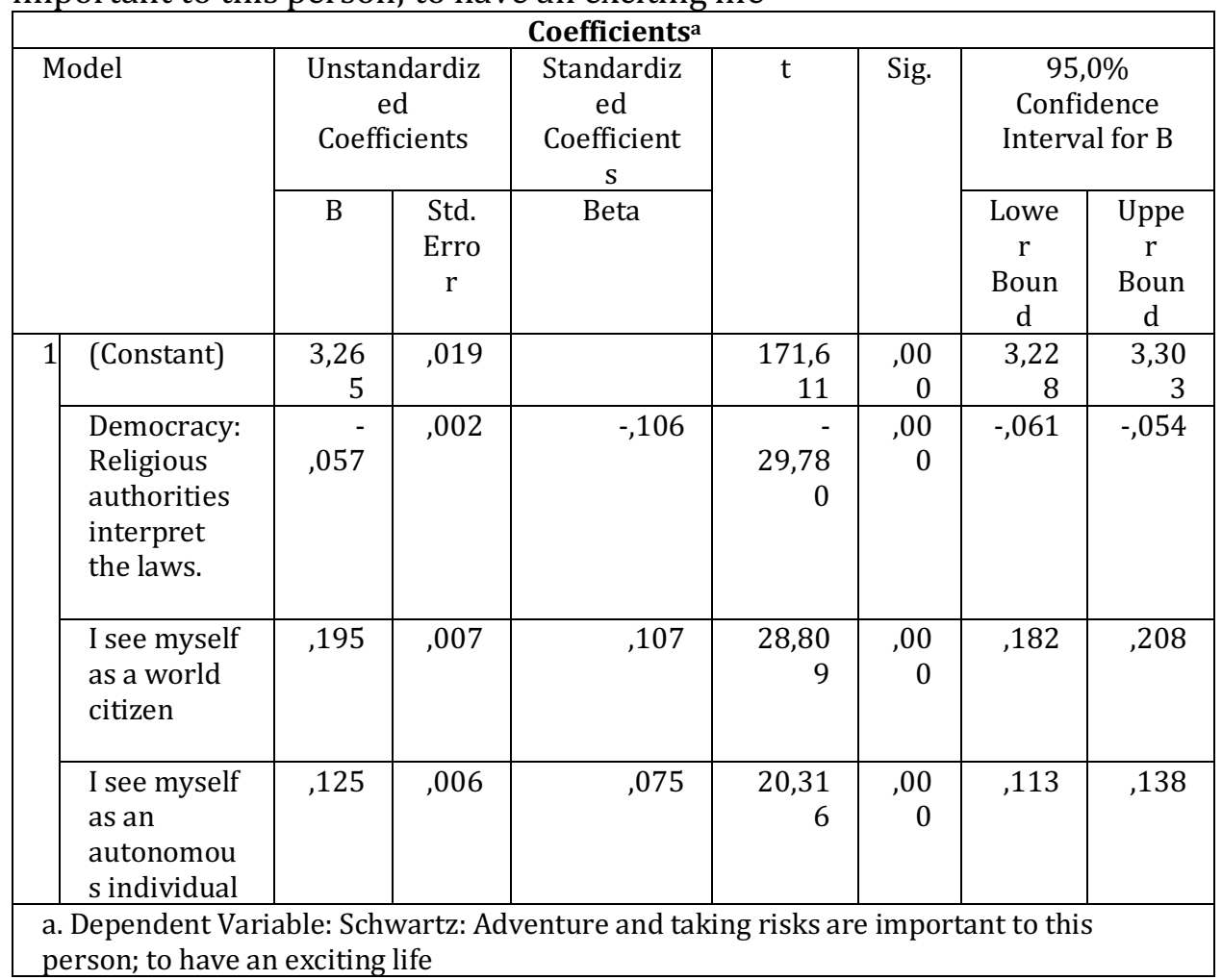


In Table 5, we can see that the three most recognized gambling factors correlated with taking risk are: having a good time; belonging (mostly referring to collectivism and individualism); and the importance of democracy in terms of the development and involvement of religion. All these factors are partially involved in the gambling culture as an important line between different types of gambling cultures described in the next chapter and represent an additional insight into gambling culture.

\section{Development of the Pro-Gambling Culture}

The paper examines the main characteristics of gambling culture along with other significant factors like the taking-risk factor, regulation, religion, etc. The following chapter presents four types of gambling culture: Simple Gambling Culture, Transitioning Gambling Culture, Denied Gambling Culture, and Pro-Gambling Culture. The conclusions are based on the reviewed literature and qualitative analysis. We basically assembled the examined gambling characteristics into one model. Still, the model is open for additional evaluations and upgrades.

Figure 1: Four types of Gambling cultures

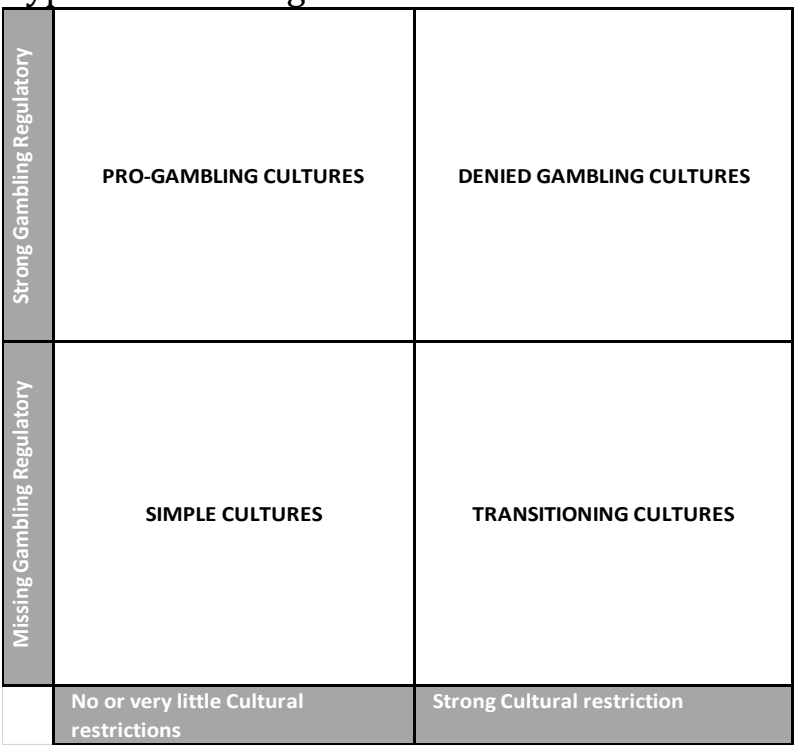

Source: Own conclusions 


\subsection{Simple Gambling Culture}

Gambling cultures which represent the Simple Gambling Culture type are mostly "simple" regarding their social structures. Simple Gambling cultures in this context may have integrated all social and economic institutions and activities, but are still struggling with social stability (welfare, politics, and internal conflicts). The primary family structure is still flexible, so nobody serious labels gambling activities as good or bad. Games of chance are played in homes or common spaces at low stakes if they are, of course, present in the community as an indigenous cultural activity. The most common cultures are the traditional cultures with survival values. Gambling can be seen as a means of having a good time or just a way to trade goods. Usually they play games of chance based on "chance" and believe in God's will (depends on the religion).

The main factors which reinforce gambling activity are the development of the state and community, the presence of foreign investors, and the impact of modernization. Introducing the monetary system or just reinforcing the meaning of money can affect individuals to such an extent that they will start looking for the answers to these inequalities at gambling places. Gambling key factors are not specifically high represented among this type of gambling culture. This type of gambling culture can be applied to some of the least developed countries (for example, some less developed parts of Africa).

\subsection{Denied Gambling Culture}

These are cultures with strong religious or cultural backgrounds which do not allow any gambling activity. The state or religion condemns all individuals who try to play games of chance. Gambling is usually a parable for losing money, violence, and everything evil on earth. We can define these cultures as traditional because the limitation is usually set by religion or strong cultural norms. The social structure can be strongly defined and laws mostly just support the cultural norms and values. The present values are specifically dictated by religious beliefs. Otherwise, if anyone is to gamble, the person is usually from the upper class or from the modernized parts of the country or region. Gambling key factors are expressed but just within a specific group of people which is part of the described type of gambling culture. The Muslim World and some Asian countries can be categorised as Denied gambling culture type.

\subsection{Pro-gambling Culture}

These cultures have a strong gambling cultural background and the only restriction is represented by the high-level structure of institutional regulatory. Usually, they are very secular with no strong religious beliefs and 
they tend to demonstrate more self-expression values. The social construct is highly complex, there are many interactions using mostly new technologies. The primary socialization accepts games of chance from the early beginnings and can perceive gambling as part of social life. Games of strategy, where the player is involved in and swamped by interactions with other players in order to make his strategic move, are more popular games than others with the Progambling culture type. At this level, we can find players transitioning from one level to another, depending on which cultural background they come from and whether they can, at this point, integrate gambling activity in their lives as something acceptable from the perspective of the society they belong to. Gambling key factors are highly expressed within this type of gambling culture. The corresponding regions are Europe, and the English-speaking ones.

\subsection{Transitioning Gambling Culture}

The main reason to transition from simple or denied gambling culture types to the pro-gambling culture type is developing a wide range of gambling characteristic. These gambling characteristics are gambling regulations, cultural acceptance, gambling infrastructure (landbased casinos, online software, etc.), and other inclinations. However, when these characteristics are not fully developed but are in the middle of the process, we understand this position as transition. This is why we define them with the term Transitioning Gambling Culture type.

Developing countries and those already developed still have strong cultural backgrounds and struggle to accept gambling as something acceptable. They can be categorized as the Transitioning Gambling Cultures type. Moving around the world together with massive tourism open all cultures to multiculturalism introducing a new badge of norms and values, which can be in strong conflict with their native culture and identity. Considering game preferences, we can conclude that transitioning cultures prefer games with less strategy, they mostly rely on chance, also in combination with physical-skill games. Secularization is either not finished yet, it will never conclude, or the political influence denying gambling is stronger than gambling trends within the gambling culture. The corresponding regions where the trend is observed are some parts of Asia (for example China), the Middle East, some parts of Latin America, and others.

Countries in transition are mostly in the middle of a regulating process, meaning that their laws may be lenient or not defined properly, but can, however, be very strict. This depends on whether they are transitioning from Simple countries or Denied countries. 


\section{Discussion}

For its development, gambling activity undergoes an intense social and cultural transformation linear with modernization and social development. It is the culture together with social adaptation that plays the key role in interpreting gambling. The Pro-Gambling Culture type, as defined in this paper - the new era of gambling co-existing with the society through regulatory - brings a new aspect of gambling at the level of development of the gambling culture in modern societies. The association between societal complexity and gambling is explained by the type of social structures and interactions. Moreover, global technologies take over all aspects of social life and gambling sites are not an exception. Gambling gives them pleasure and excitement to fulfil either their self-expression values or just the need for competitiveness and leisure. At this point, gambling unites different parts, what was artificially created by modernization, the collectivistic and individualistic worlds, traditional and modern worlds. Gambling activities can be accepted over time, hence concluding that any culture can develop ProGambling culture and is either transitioning from Simple Gambling Culture, Denied Gambling Culture or Transitioning Gambling Culture types.

\section{References}

Arnold, Peter. 1977. The Encyclopedia Of Gambling. The Game, the Odds, the Techniques, the People and Places the Myths and Hystory. London: Chartwell Books Inc.

Binde, Per. 2003. "Gambling and Religion: Histories of Concord and Conflict." Gambling and Religion Journal of Gambling Issues 20: 145-65. DOI: 10.4309/jgi.2007.20.4.

Binde, Per. 2005. "Gambling Across Cultures: Mapping Worldwide Occurrence and Learning from Ethnographic Comparison." International Gambling Studies 5 (1): 1-27. DOI: 10.1080/14459790500097913.

Hofstede, Geert, Gert, Jan Hofstede, and Michael Minkov. 2010. Cultures and Organizations: Software of the Mind: Intercultural Cooperation and Its Importance for Survival. Cultures and Organizations. New York: McGraw-Hill. DOI: $10.1007 / \mathrm{s} 11569-007-0005-8$.

IGaming Business. 2018. IGaming Dashboard - December 2018. www.igamingbusiness.com/igaming-dashboard-december-2018. 
Accessed 10.8.2019.

Inglehart, Ronald, Christian Welzel, R. Inglehart and C. Welzel. 2005. Modernization, Cultural Change, and Democracy: The Human Development Sequence. Cambridge University Press.

Inglehart, Ronald, Haerpfer, Christian W., Moreno Alejandro, Welzel Christian, Kizilova Kseniya, Diez-Medrano Juan, Lagos Martin, Pippa Norris, Eduard Ponarin, and Bi Puranen. 2014. 'WVS Database'. World Values Survey: Round Six. Madrid: JD Systems Institute. DOI: 20.06.2017.

Inglehart, Ronald, and Christian, Welzel. 2018. "World Values Survey: Findings and Insights." www.worldvaluessurvey.org/WVSContents.jsp?CMSID=Findings. Accessed: 14.8.2019

LaTour, Kathryn A., Franck, Sarrazit, Rom Hendler, and Michael S. LaTour. 2009. "Cracking the Cultural Code of Gambling." Cornell Hospitality Quarterly 50 (4): 475-97. DOI: 10.1177/1938965509345241.

McMillen, Jan. 2005. "Understanding Gambling: History, Concepts and Theories." In Gambling Cultures: Studies in History and Interpretations, edited by Jan McMillen, 1st ed., 6-39. London and New York: Routledge. DOI: $10.4324 / 9780203993507$.

Rapaille, Clotaire. 2006. The Culture Code: An Ingenious Eay to Understand Why People Around the World Buy and Live As They Do. New York: Broadway Books.

Raylu, Namrata, and Tian Po Oei. 2004. "Role of Culture in Gambling and Problem Gambling." Clinical Psychology Review 23 (8): 1087-1114. DOI: 10.1016/j.cpr.2003.09.005.

Reith, Gerda. 2005. The Age of Chance. Gambling in Western Culture. London and New York: Routledge.

Roberts, John M, Malcolm J Arth, and Robert R Bush. 1959. “Games in Culture.” New Series 61 (4): 597-605.

Thompson, William Norman. 2015. Gambling in America: An Encyclopedia of 
History, Issues, and Society. 2nd ed. Journal of Chemical Information and Modeling, Vol. 53. California: ABC-CLIO, LLC.

Westwood, Robert. 2014. "De-Centring Management and Organisation Studies: On the Eccentricity of US-Based Management and Organization Theory and Practice." In Core-Periphery Relations and Organization Studies, edited by Robert Westwood, Gavin Jack, Farzad Khan, and Michal Frenkel, First, 53-78. United Kindom: Palgrave Macmillan.

DOI: $10.1057 / 9781137309051$.

Westwood, Robert, Gavin, Jack, Farzad, Khan, and Michal, Frenkel, eds. 2014. Core-Periphery Relations and Organization Studies. Palgrave Macmillan. DOI: $10.1057 / 9781137309051$.

World Casino Directory. 2018. www.worldcasinodirectory.com. Accessed 19.8.2019. 